\title{
Exchange rate volatility and its effect on intra-East Africa Community regional trade ${ }^{1}$
}

\author{
Thomas Mosbei* \\ Silas Kiprono Samoei** \\ Clement Cheruiyot Tison*** \\ Edwin Kipyego Kipchoge****
}

\begin{abstract}
East Africa Community (EAC) exchange rate volatility spiraled up when the countries adopted the Structural Adjustment Policies in early 1980s. The question that remains unanswered is whether exchange rate volatility hinders or promotes trade. The objective of this study was to determine the effect of exchange rate volatility and its effect on Intra-East Africa Community regional trade. Unit root tests results indicated that some of the variables were stationary, and on first difference all variables were I(1). Differenced panel data was fitted into a General Autoregressive Conditional Heteroscedasticity model to measure volatility. Hausman test showed that the fixed effect model was appropriate, exchange rate, money supply, population, and foreign direct investment significantly determines intra-East Africa Community regional trade. It was concluded that exchange rate volatility is observable in the Intra-East Africa region and further, exchange rate, money supply, population, and foreign direct investment significantly influenced intra-EAC regional trade. It is recommended that EAC member states should formulate policies that ensures exchange rate stability in the region to reduce unpredictability of exchange rate. Policies should be enacted to guarantee adequate money supply and encourage foreign direct investments.
\end{abstract}

Keywords: East African Community, GARCH, Unit root and Exchange rate Volatility.

\section{Resumen}

La volatilidad de los tipos de cambio en la Comunidad de África Oriental se disparó cuando los países adoptaron las Políticas de Ajuste Estructural a principios de la década de 1980. La pregunta que permanece sin respuesta es si la volatilidad del tipo de cambio obstaculiza o promueve el comercio. El objetivo de este estudio fue determinar el efecto de la volatilidad del tipo de cambio y su efecto en el comercio intra-regional de la Comunidad de África Oriental. Los resultados de las pruebas de raíz unitaria indicaron que algunas de las variables eran estacionarias, y en primera diferencia, todas las variables eran I(1). Por esto, los datos de panel diferenciados se ajustaron a un modelo general de heterocedasticidad condicional auto-regresivo para medir la volatilidad. La prueba de Hausman mostró que el modelo de efectos fijos era apropiado, y que el tipo de cambio, la oferta monetaria, la población y la inversión extranjera directa determinan significativamente el comercio intra-regional de la Comunidad de África Oriental. Se concluyó que la volatilidad del tipo de cambio es observable en la región de África Oriental y, además, el tipo de cambio, la oferta monetaria, la población y la inversión extranjera directa influyeron significativamente en el comercio intra-regional. Se recomienda que los Estados miembros de la Comunidad de África Oriental formulen políticas que aseguren la estabilidad del tipo de cambio en la región para reducir la imprevisibilidad del tipo de cambio. Deben promulgarse políticas para garantizar una oferta monetaria adecuada y fomentar las inversiones extranjeras directas.

Palabras Claves: Comunidad de África Oriental, GARCH, Raíz unitaria, volatilidad del tipo de cambio.

\footnotetext{
${ }^{1}$ This article is a revised and expanded version of a thesis entitled 'Exchange rate volatility and its effect on intra-East Africa Community regional trade' presented at Moi University, Eldoret, Kenya for award of masters degree in Agricultural Economic and Resource Management.

*Department of Agricultural Economics, Moi University. Email address: mosbeithomas@gmail.com. Received: October 1st, 2020; modifications: April 10th, 2021; accepted: April 24th, 2021.

** Department of Agricultural Economics, Moi University.

*** Department of Economics, Moi University.

**** Department of Mathematics and Computer Science, University of Eldoret.
} 
Thomas Mosbei - Silas Kiprono Samoei - Clement Cheruiyot Tison - Edwin Kipyego Kipchog

Exchange rate volatility and its effect on intra-East Africa Community regional trade

\section{Introduction}

The history of exchange rate volatility dates back to 1973, when Bretton Woods structure of immovable parities (which had its headquarters in New Hampshire) collapsed. This fall resulted in the implementation of fluctuating currency charge regimes by world economies. Throughout these uncontrolled currency conversion systems, movements in money conversion rate have remained uncertain, resulting in some unpredictable and undesirable effect on the balance of trade (SosvillaRivero, 1991). While some economies welcomed the idea, others protested and warned on the negative effect, arguing that free volatile rate of exchange could have adverse effects on a country's exports. They argued that that unexpected variation of the exchange rates causes undesirable influence of risk to producers and makes them to alter or change their sales to home markets thus negatively affecting the overall level of trade.

The rise of exchanges rates besides prominence of intra-regional line of work for many emerging nations of the world, has amplified the degree of the real properties of its variation in bilateral rates amongst neighboring developing countries (Jadresic et al., 2001). Musyoki et al., (2012) defined the rate of exchange as the charge of one nation legal tender in terms of another nation's legal tender. Owing to severe macroeconomic disproportions in the early 1980s and 1990s, most Sub-Saharan African countries went on board to implement changes to liberalize their markets. The transformations commenced enclosed exchange rate and global trade liberalization in concurrence with structural adjustment policy transformations (Mwangi et al., 2014). From here, the general objective of this research was to determine the effect of exchange rate volatility and selected macroeconomic variables on intra-East Africa community regional trade.

\section{Literature Review}

\section{Exchange Rate Volatility and International Trade}

Implementation of uncontrolled exchange rate coordination from the cessation of Bretton Woods has initiated a huge improbability in currency conversion rate. Several theoretical studies support the negative proposition that oscillating currency conversation rates obstructs trade (Shapiro, 2009). Other studies concluded that volatile exchange rate promotes global or trade across national borders (Franke, 1991), although other several empirical results have yielded insignificant findings.

Eichengreen and Gupta (2013) studied the effect of volatile rate of currency conversion on service exports in unindustrialized nations by setting apart contemporary from old-style services. They point out that actual rate of currency conversion exaggerated transfers of commodities and traditional services in the same way but affected modern services by greater proportion. The study concluded that money devaluation may possibly be engaged as a tool designed for advancement in a short period, since a country could not indefinitely resist a devalued currency.

Hooper and Kohlhagen (1978) stated that volatile exchange rate system hampers international trade. They argued that higher volatility results in greater charges for merchants who will thereafter reduce participating effort in foreign trade to avoid risk. On the other hand, De Grauwe (1988) suggested the opposite, arguing that if exporters adequately avoid risks, amplified unpredictability will intensify the anticipated marginal value of export earning and thus enhance exports. Todani and Munyama (2005) noted that exchange rate across East Africa Community has not been stable in relation to the United States currency, especially after the demise of Bretton woods which was the only structure of 
Thomas Mosbei - Silas Kiprono Samoei - Clement Cheruiyot Tison - Edwin Kipyego Kipchog

Exchange rate volatility and its effect on intra-East Africa Community regional trade

stable currency regime worldwide. The study also concluded that currency conversion rate increased further due to the introduction of SAPs in the early 1990s.

\section{Foreign Direct Investment and International Trade}

Foreign direct investment (FDI) is one of the most important factors in an open and successful international trade and a major tool for development and prosperity. FDI has the following benefits: technology transfer, support for the formation of human capital, improvement of competitive business environment, contribution to international trade integration, and the promotion of development. Economically, FDI can support the improvement of environment and social condition in the host country by relocating 'cleaner' technology, orientating to more socially responsible corporate policies thus mitigating the global warming challenge. These benefits contribute to higher economic growth, which is the main instrument for alleviating poverty in an economy.

Benefits from FDI show a discrepancy from one country to another, making it difficult to separate and measure them (UNCTAD, 2006). The impact of FDI on the international trade of a host country differs, depending on whether it seeks to be efficient, market seeking, resource seeking or strategic asset seeking. FDI can have a greater contribution to economic growth in developing countries by supporting their export growth. Output resulting from efficiency-seeking FDI is typically anticipated for export, and therefore the effect of such FDI is most likely to be an increase in the host country's exports.

Albulescu et al., (2016) studied the relationship between trade and FDI in Central and Eastern European countries, concentrating mainly on Hungary, Czech Republic, Poland, and the Republic of Slovakia. The study used a panel gravitational model for each country for the bilateral trade and FDI, considering its interactions with the other three economies and with the three European Union leading profitmaking trading partner. The study analyzed uneven surfaces of the trade - FDI nexus, using a fixed effects model, a random effects model, as well as an instrumental variable estimator, over the period 2000 - 2013. Findings suggested that FDI tolerates the trade partnership of Central and Eastern Europe (CEE) states, whereas interior FDI does not have substantial influence.

\section{Effect of Inflation on International Trade}

Inflation is defined as a continued escalation of the general price level of a nationwide budget assumed either at the retail or wholesale level. The annual rate of conversion in this price level, generally articulated in index numbers, is the inflation rate. Amadeo (2012) refers to them as moments in which the values of many business transactions continue towards the sky. At such moments, average living standards deteriorate as consumer prices increase the cost of living. According to various schools of thought, inflation is a financial spectacle; therefore, the reduction of inflation is fundamentally the objective of the financial strategy.

This argument is based on the theory of the magnitude of the currency, which proposes that inflation is determined exclusively by the alteration of the comparative flow of currency and merchandise. Inflation echoes a drop in purchasing power over the unit of cash, that is, money loses value during inflation. The effects of inflation in an economy can be helpful or undesirable. Undesirable effects include the people holding money due to hesitation about forthcoming inflation. Ultimately, this discourages investment and saving, and if inflation dissolves sufficiently, shortage of commodities as customers hoard out of concern that prices would increase in the future. Positive effects occur when 
Central Banks of countries adjust real interest rates in order to mitigate recessions and promote investment in nonmonetary capital projects (Heise, 2019).

\section{Money Supply and International Trade}

Money supply is the total of financial possessions obtainable in a country at a certain period (Hina \& Ullah, 2019). They also include legal tender in circulation and demand for guarantees of monetary organizations. Monetary policy plays a critical role in bringing order to the financial sector. It ensures competition in the commercial sector and the evolution of important environments for the growth of commerce and industry. Economically, a lower interest rate creates a conducive environment for the economy to prosper. A decrease in the interest rate offers a common eventuality for taking equity capital expenditures firsthand, as well as sing the firm's faith by making substantial investments in the growing segment and generating huge profits. High interest rates reduce trade because they are regularly associated with high inflation.

Money supply has a resilient influence on economic motion because it is the only mode of exchange in business. This suggests that if there could be an increase in money supply, the outcome is a decrease in interest rates thus high economic growth and development. Manufacturers recognize improving by pooling additional resources and intensifying their manufacturing capacity. As soon as trade prospers, the response for employment and investment goods increases. Stock market prices rise and companies issue more stocks and debt. In this perspective, the money supply has continued to expand. Prices start to rise if production growth reaches capacity limits. People start to expect inflation and lenders demand higher interest rates, while consumer purchasing power decreases over the life of their loans.

\section{Population and International Trade}

A research by Mckoy (2007) concluded that population has a strong affinity to increased trade and the level of specialization by generating gains from specialization. On the contrary, Dell Ariccia (1999) found a negative coefficient. For a negative relationship between population and trade movements, the study recommended that imports and exports are capital intensive in production. The effect of population on trade is also different depending on whether the estimate is short-term or long-term. In the short term, it can have a positive impact on trade flows because many products are exported as a result of an increase in the labor force and an increase in the level of specialization. In the long run, as the population increases, per capita income also declines, impoverishing each individual, resulting in a decline in both production and exports.

From a microeconomic point of view, the lower per capita income also causes a decrease in the demand for imports. Mohsen \& Chua et al., (2015) conducted a research to investigate the role of trade openness, investment and population in Syria and used the time series data from 1980 - 2010. Cointegration test results point out that the GDP is significantly and positively correlated to the trade openness, investment, and population. The results of the Granger causality test designate a bidirectional connection of short-term causality between trade openness, investment, population, and GDP.

There are also long-term two-way causality relationships between investment, population, and GDP, and long-term, one-way causality relationships ranging from trade openness to GDP. The study's findings point out that population had the main effect on GDP, so the study suggested improving 
Thomas Mosbei - Silas Kiprono Samoei - Clement Cheruiyot Tison - Edwin Kipyego Kipchog

Exchange rate volatility and its effect on intra-East Africa Community regional trade

the quality of human capital in the country, as well as refining investment and opening the Syrian economy to the global market.

\section{Methodology}

\section{Research Design}

Longitudinal design was used in the study. Panel data methodology allows the testing and modifications of assumptions that are contained in cross-sectional analysis (Maddala \& Wu, 2001; Baltagi, 2005). Panel data provides more facts, more variability and competition, as well as capturing and measuring effects that are not noticeable in cross-sectional examination. The design is appropriate for tracking changes over time and relates them to variables that could explain why the changes occur. Measurements are taken on each variable over two or more different time periods. This allows the researcher to measure the change in the variables over time. The longitudinal research design allows analysis of the duration of a particular phenomenon under investigation. The design allows the measurement of differences or changes in a variable from one period to another (that is, the description of patterns of change over time) and allows the prediction of future results based on the above.

\section{Study Area}

The study was conducted in East Africa region which covers an area of approximately 1.82 million square kilometers with a population of approximately 196 million people as of 2017 (Resnick, 2017). It comprises five countries: Republic of Kenya, the Republic of Burundi, Republic of Rwanda, Republic of Uganda and United Republic of Tanzania. EAC has its headquarters in Arusha, Tanzania and its official language is English (World Bank, 2017).

\section{Sources of Data}

The data for this study was obtained from World Bank, Kenya National Bureau of Statistics, World Integrated Trade Solution and Central Banks of every member state under study.

\section{Target Population}

The research targeted selected East Africa Community member states. These are Kenya, Uganda, Tanzania, Rwanda and Burundi. These countries have similar social, economic, and political characteristics. Moreover, they are members of the same economic bloc. South Sudan was omitted due to unavailability of complete data because it became a full East African Community member in 2016 (UNCTAD, 2018).

\section{Stationarity Test}

A variable is stationary if its mean, variance, and autocovariance remain constant regardless of where the measurement is taken. If a time series variable has a unit root where the time series data does not have a constant variance and to avoid reporting false results arising from regression of non-stationary data on one or more non-stationary data, the variables are differentiated to achieve stationarity (Gujarati, 1999). 
The Levin-Lin-Chu panel data unit root test was also performed on the following model.

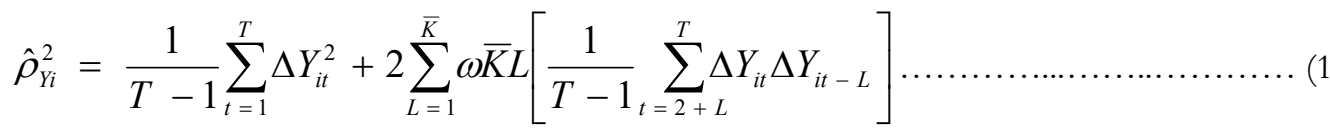

Where $\varepsilon_{t}$ is a white noise series, when $\rho=1$ it designates existence of unit root $0<\rho<1$ denotes stationarity (Choi, 2006; Phillips \& Moon, 1999).

\section{Measurement of Volatility using the GARCH Model}

GARCH $(p, q)$ model was estimated to obtain the exchange rate volatility. First-order autoregressive (AR) processes of order one (1) is followed. GARCH model gives good prediction of effective exchange rate volatility. In its simplest form, the GARCH model can be written as:

$\sigma_{t=}^{2} \omega+\propto \mathrm{U}_{n-1}^{2}+\beta \sigma_{t-1}^{2} d_{n-1}+\gamma \delta_{n-1}^{2}+\varepsilon_{t}$

Where;

$\sigma_{\mathrm{t}=}^{2}$ is the conditional variance of exchange rate for the previous year, $\propto, \beta$ and $\gamma$ are the coefficients, $\mu_{n-1}^{2}$ is the mean square of the previous year and $d_{n}$ takes the value of 1 for $\mu_{t}<0$ and 0 otherwise. This is the general GARCH $(p, q)$ model, with $p$ lagged terms of the squared error term and $q$ terms of the lagged conditional variance.

\section{Specification of Econometric Model}

$\log E X P_{i t}=\beta_{0}+\beta_{1} \log E X R V_{i t}+\beta_{2} \log E X R_{i t}+\beta_{3} \log M Y S_{i t}+\beta_{4} \log I N F_{i t}+\beta_{5} \log P O P_{i t}+$

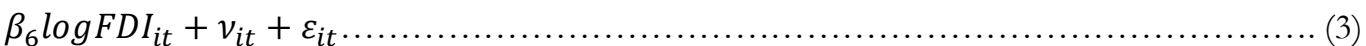

Where; $E X P_{i t}$ is the sum of all tradables from one country to another measured in US dollars; $E X R V_{i t}$ is the exchange rate volatility; $E X R_{i t}$ is the exchange rate of each country in relation to the US dollar; $M Y S_{i t}$ is the money supply (made up of M1 and M2) measured in USD; INF $F_{i t}$ is the inflation in rate; $P O P_{i t}$ is the population growth of a particular member country in millions; $F D I_{i t}$ is the foreign direct investment in USD; $v_{i t}$ is the individual specific effects (assumed to be correlated in fixed effects model and uncorrelated in random effects model); $\varepsilon_{i t}$ is the error term; $\beta_{0}$ is the intercept; $\beta_{1}-\beta_{6}$ are the parameter estimates; $t$ is the time trend; and $i$ is cross-sectional units. In this study, $E X P_{i t}, M Y S_{i t}$ and $P O P_{i t}$ were transformed into logarithmic form to remove skewness and make the data conform to normality.

\section{Results and Discussion}

\section{Stationarity}

From the results presented in Table 1, trade, population, FDI, exchange rate, money supply, and exchange rate volatility contain the unit root in levels. It was found that the inflation rate does not 
Thomas Mosbei - Silas Kiprono Samoei - Clement Cheruiyot Tison - Edwin Kipyego Kipchog Exchange rate volatility and its effect on intra-East Africa Community regional trade

contain a unit root in the levels. The use of non-stationary variables in regressions could lead to spurious results and, therefore, it was necessary to use differentiated variables.

Table 1: Results of Levin - Lin - Chu Test

\begin{tabular}{lll|l|lll}
\hline \multicolumn{3}{l}{ Variables at Levels } & \multicolumn{2}{l}{ First Difference } & \\
\hline Variable & $\mathrm{z}$ inverse normal & $\mathrm{p}$ - value & Remarks & $\mathrm{Z}$ & $\mathrm{p}$-value & Remarks \\
\hline EXPT & 0.1957 & 0.5776 & Unit root & -5.6771 & $0.0000^{*}$ & $I(1)$ \\
POP & 1.6035 & 0.9456 & Unit root & -3.1340 & $0.0000^{*}$ & $I(1)$ \\
INF & -3.6177 & $0.0001^{*}$ & Stationary & -3.1340 & $0.0000^{*}$ & $I(0)$ \\
FDI & 0.6785 & 0.7512 & Unit root & -9.2666 & $0.0000^{*}$ & $I(1)$ \\
ERT & 2.2365 & 0.9875 & Unit root & -4.3296 & $0.0000^{*}$ & $I(1)$ \\
MYS & 0.8544 & 0.8036 & Unit root & -3.2680 & $0.0000^{*}$ & $I(1)$ \\
ERV & 0.3551 & 1.0024 & Unit root & 1.9800 & $0.0465^{*}$ & $I(1)$ \\
\hline
\end{tabular}

Source: Authors own compilation from Stata output (2019)

One of the approaches of dealing with spurious regression is testing whether each of the multiple series is $I$ (1). In the first difference, all variables were stationary at the 5 percent level of significance. The Levin-Lin-Chu bias-adjusted test statistic $\mathrm{t} * \delta=-4.0277$ is significantly less than zero $(\mathrm{p}<0.05)$, thus the null hypothesis of unit root was rejected (that is, that $\varphi=0$ a favor of the alternative hypothesis). Based on the Hausman test, Prob $>$ chi $2=0.000$ was estimated. The null hypothesis that random effects are better than fixed effects was rejected and fixed effects were adopted. This implies that the country-specific effects are correlated with the independent variables and, therefore, the fixed effects model was used to test hypotheses.

\section{Exchange Rate Volatility}

To measure exchange rate volatility, the study employed the generalized autoregressive conditional heteroskedasticity (ARCH/GARCH). The coefficient of exchange rate volatility is positive and statistically significant at $5 \% \beta=1.0908$ and $(P=0.000<0.05$. It implies that a one percent increase in exchange rate volatility in EAC, trade increases by 1.0908 percent.

Table 2: Results of ARCH/GARCH Model

\begin{tabular}{rlllllc}
\hline ERV(USD) & Coef. & Std Err & $\mathrm{Z}$ & $\mathrm{P}>|\mathrm{Z}|$ & \multicolumn{2}{l}{$95 \%$ Conf. Interval } \\
\hline Cons & 0.9379 & 0.0012 & 75.61 & 0.000 & 0.0936 & 0.0922 \\
ARCH & & & & & \\
L1 & 1.0908 & 0.2590 & 4.22 & 0.000 & 0.5837 & 1.5978 \\
GARCH & & & & & \\
L1 & 0.0007 & 0.0013 & 0.57 & 0.569 & -0.0018 & 0.0033 \\
Cons & $2 . .23 \mathrm{e}-06$ & $9.53 \mathrm{e}-06$ & 0.23 & 0.815 & -0.00001 & 0.00002 \\
\hline
\end{tabular}

Source: Authors own compilation from Stata output (2019)

If traders are risk averse, high exchange rate volatility increases the expected marginal utility of export earnings and thus improves exports. These findings fit the risk portfolio theory with the conjecture that higher risk implies higher returns. Therefore, the increased risk due to fluctuations in exchange rates could rather increase the volume of trade (Senadza and Diaba, 2017). 


\section{Table 3: Fixed Effects Model}

\begin{tabular}{|c|c|c|c|c|c|c|}
\hline \multicolumn{7}{|c|}{ Regression Results for Fixed Effects Model } \\
\hline \multicolumn{7}{|c|}{ Number of Obs. $=78$} \\
\hline $\mathrm{F}(6 ; 55)$ & $=114.57$ & & & & & \\
\hline Prob $>$ F & $=0.000$ & & & & & \\
\hline $\mathrm{R}$ square & $=0.5971$ & & & & & \\
\hline EXPORTS & Coef. & Std. Err & $\mathrm{t}$ & $\mathrm{p}>|\mathrm{t}|$ & {$[95 \%$} & Conf. Interval \\
\hline POP & 2.6362 & 0.8842 & 2.98 & 0.004 & 8.7230 & 4.4001 \\
\hline INF & -0.0010 & 0.0130 & -0.08 & 0.936 & 0.0265 & 0.0244 \\
\hline FDI & 0.2018 & 0.0426 & 4.74 & 0.000 & 0.1183 & 0.2852 \\
\hline EXT & -0.0008 & 0.0001 & -5.64 & 0.000 & -0.0011 & -0.0005 \\
\hline MYS & 2.9468 & 0.3025 & 9.74 & 0.000 & 2.3407 & 3.5530 \\
\hline ERV & 3.5675 & 0.7918 & 4.51 & 0.000 & 1.9809 & 5.1540 \\
\hline CONS & -42.3022 & 2.5015 & -16.91 & 0.000 & $-4 / .3153$ & -37.2891 \\
\hline
\end{tabular}

Source: Authors own compilation from Stata output (2019)

Population (POP) has positive and significant effect on Intra East African Trade ( $\mathrm{p}$-value $0.0040<$ $0.05)$ at $5 \%$ level of significance. It had a positive coefficient of 2.6362 which shows that a unit increase in population implies increase in Intra East African trade. The study interprets this positive population effect that the increase in population causes an increase in the market. Larger population implies more supply of labor force and improved labor specialization which implies more production and more goods for both domestic and foreign markets. Moreover, population increase may lead to increased demand for imported goods as well. The findings follow earlier studies by Mohsen, et al., (2015). On the contrary, studies by Nuroglu (2010) and Ambetsa et al (2019) found a negative relationship between population and trade among the EAC member states. They argued that a higher population causes a higher dependence ratio and condensed income per individual which makes people poorer leading to low production and finally decline in international trade.

The fixed effect regression results showed that inflation (INF) had no significant effect on Intra East African Trade. FDI had positive and significant effect on Intra East African trade ( $\mathrm{p}-$ value $0.0000<$ 0.05). A unit increase in foreign direct investment causes a 0.2018 -unit increase trade. Driven by the progressive liberalization of trade policies, the politically stable environment and the availability of factors of production or resource endowments in the region attract foreign direct investment.

Fixed effects model showed that exchange rate (EXT) is a vital determinant of Intra East African trade $(\mathrm{p}-$ value $<0.05)$. The coefficient showed that a unit change in exchange rate results in a decrease in Intra East African trade by 0.0008 units. An increase in the exchange rate fluctuation would lead to a reduction in foreign trade because there are costs associated with exchange rate variability and these reduce the incentive to trade. Furthermore, the negative exchange rate coefficient implies that the depreciation of the currency will cause a reduction in international trade because it will increase the cost of imports.

Money supply (MNS) registered a positive and significant effect on Intra East African trade ( $\mathrm{p}$ - value $<0.05$ ). A unit increase in money supply leads to 2.9468 units increase in Intra East African trade. This affiliation concerning money supply and Intra East African trade is because an increase in the supply of money raises the income level. Due to the higher per capita income, people feel better and this motivates people to venture into production. A high production implies that more goods will be used for the domestic market and the surplus will be exported to external markets. Manufacturers 
will demand raw materials and when companies prosper, more workers with better wages will be employed. Importing products for which a country has a comparative disadvantage in production will not present any challenge because individuals are fine.

The coefficient of exchange rate volatility is positive and statistically significant at $5 \% \beta=1.0908$ and $(P=0.000<0.05$. It implies that a one percent increase in exchange rate volatility in EAC, trade increases by 1.0908 percent. These findings can be interpreted in such a way that if traders are risk averse, the high volatility of exchange rates increases and thus the expected marginal utility of export earnings improves exports. These findings follow risk-portfolio theory with the conjecture that higher risk implies higher returns. Thus, increasing risk due to fluctuating exchange rates could rather increase the volume of trade (De Grauwe, 1996).

\section{Conclusion and recommendation}

It can be concluded that in Intra-East Africa Community region, exchange rate volatility is observable. In addition, exchange rate, money supply, population, and foreign direct investment have an influence on intra-EAC regional trade. Furthermore, there is need for partner states of EAC to enact and implement laws and policies that are geared towards stabilization of exchange rates without resorting to foreign exchange interventions to attract and encourage foreign investors and to create a conducive environment for investment. From the findings, population has come out to be a significant factor for foreign trade.

Therefore, partner states in the EAC should formulate and pass laws that increases both the size and maintain population at par with economy to spur economic growth. A considerable population implies that citizens receive a quality education, medical attention that is translated into specialized labor, thus increasing production for export and the consumption of locally manufactured goods. EAC member states should formulate policies that help streamline the functions of their financial markets to ensure efficient credit issuance and foster financial development. The EAC member states must formulate policies that strengthen their institutional framework to guarantee the proper functioning of the markets. Weak institutional frameworks frequently change laws, creating inefficiencies in public administration that hamper FDI. 


\section{References}

Albulescu, C. T., \& Goyeau, D. (2016). The interaction between trade and FDI: the CEE countries experience. arXiv preprint arXiv:1609.02334.

Amadeo, K. (2012). Obamacare Bill: A Summary of the Bill's 10 Titles. About. com.

Ambetsa, W. O, Kenneth P. Mdadila \& Longinus K. Rutasitara (2019). The Determinants of Bilateral Trade in the East African Community: Application of the Gravity Model. International Journal of Economics and Finance; Vol. 11, No. 4; 2019

Baltagi, B. H. (2005). Econometric Analysis of Panel Data 3rd Edition England JW \& Sons.

Choi, I. (2006). Combination unit root tests for cross-sectionally correlated panels. Econometric Theory and Practice: Frontiers of Analysis and Applied Research: Essays in Honor of Peter CB Phillips. Cambridge University Press, Chapt, 11, 311-333

Dell'Ariccia Giovanni (1999) "Exchange Rate Fluctuations and Trade Flows: Evidence from the European Union". IMF Staff Papers 46(3): 315-334

De Grauwe, P. (1988). Exchange rate variability and the slowdown in growth of international trade. Staff Papers, 35(1), 63-84

De Grauwe, P. (1996). Monetary union and convergence economics. European Economic Review, 40(3-5), 1091-1101.

Gujarati, D. N., \& Porter, D. C. (1999). Essentials of econometrics (Vol. 2). Singapore: Irwin/McGraw-Hill.

Heise, M. (2019). Inflation Targeting and Financial Stability: Monetary Policy Challenges for the Future. Springer.

Hina, M., \& Ullah, A. (2019). The Role of Money Supply: Foreign Direct Investment \& Economic Growth in Pakistan. International Journal of Economics, Commerce and Management, 7(2), 281-289.

Hooper, P., \& Kohlhagen, S. W. (1978). The effect of exchange rate uncertainty on the prices and volume of international trade. Journal of international Economics, 8(4), 483-511.

Jadresic, E., Masson, P., \& Mauro, P. (2001). Exchange rate regimes of developing countries: Global context and individual choices. Journal of the Japanese and International Economies, 15(1), 68-101.

Maddala, G. S., \& Wu, S. (2001). A comparative study of unit root tests with panel data and a new simple test. Oxford Bulletin of Economics and statistics, 61(S1), 631-652.

McKoy, S. D. (2007). The Impact of Multilateral Trade Association Membership on Agricultural and Food Trade (Doctoral dissertation, North Dakota State University).

Mohsen, A. S., \& Chua, S. Y. (2015). Effects of Trade Openness, Investment and Population on the Economic Growth: A Case Study of Syria. Hyperion Economic Journal, Year, 3(2), 3.

Musyoki, D., Pundo, M., \& Pokhariyal, G. P. (2012). Real exchange rate volatility in Kenya. Journal of Emerging Trends in Economics and Management Sciences, 3(2), 117-122.

Mwangi, S. C., Mbatia, O., \& Nzuma, J. M. (2014). Effects of Exchange Rate Volatility on French Beans Exports in Kenya.

Nuroglu, E. (2010). The Impact of Population on Bilateral Trade Flows in the Case of OIC. Working Paper, International University of Sarajevo.

Phillips, P. C., \& Moon, H. R. (1999). Linear regression limit theory for non-stationary panel data. Econometrica, 67(5), 1057-1111.

Resnick, D. (2017). Democracy, decentralization, and district proliferation: The case of Ghana. Political Geography, 59, 47-60.

Senadza, B., \& Diaba, D. D. (2017). Effect of exchange rate volatility on trade in Sub-Saharan Africa. Journal of African Trade, 4(1-2), 20-36.

Shapiro, I. (2009). The state of democratic theory. Princeton University Press

Sosvilla-Rivero, S. (1991). Asset-market models of exchange-rate determination: Basic models, empirical evidence and extensions.

Todani, K. R., \& Munyama, T. V. (2005, November). Exchange rate volatility and exports in South Africa. In TIPS/DPRU Forum (Vol. 30).

UNCTAD (2006). East Africa Community Regional Integration: Trade and Gender implications. UNCTAD (2018). East Africa Community Regional Integration: Trade and Gender implications. 
Thomas Mosbei - Silas Kiprono Samoei - Clement Cheruiyot Tison - Edwin Kipyego Kipchog Exchange rate volatility and its effect on intra-East Africa Community regional trade

World Bank. (2017). Atlas of Sustainable Development Goals 2017: From World Development Indicators. The World Bank.

Eichengreen, B., \& Gupta, P. (2013). The real exchange rate and export growth: are services different? The World Bank.

\section{(ब) (1) ( $)$} 4.0 International License, which permits the use, adaption and sharing as long as you give appropriate credit to the original author(s) and the source. The images or other third party material in this article are included in the article's Creative Commons license, unless indicated otherwise in a credit line to the material. If materials are not included in the article's Creative Commons license and your intended use is not permitted by statutory regulation or exceeds the permitted use, you will need to obtain permission directly from the copyright holder.

To view a copy of this license, visit http://creativecommons.org/licenses/by-nc/4.0/. C The Author(s) 2021. 